Check for updates

Cite this: RSC Adv., 2019, 9, 33130

Received 9th July 2019

Accepted 11th September 2019

DOI: 10.1039/c9ra05227e

rsc.li/rsc-advances

\section{Distribution, contents and health risk assessment of heavy metal(loid)s in fish from different water bodies in Northeast China}

\author{
XiaoLi Huang, ${ }^{\text {ab }}$ DongLi Qin, (D) bei Gao, ${ }^{\text {b }}$ Qirui Hao, ${ }^{\text {Z }}$ Zhongxiang Chen, ${ }^{\mathrm{b}}$ \\ Peng Wang, ${ }^{\mathrm{b}}$ Shizhan Tang, ${ }^{\mathrm{b}}$ Song Wu, ${ }^{\mathrm{b}}$ Haifeng Jiang ${ }^{\mathrm{b}}$ and Wei Qiu*ac
}

\begin{abstract}
This study aimed at investigating the accumulation and potential risks of eight metal(loid)s in fish from natural and culturing water samples in Northeast China. Chromium ( $\mathrm{Cr}$ ), nickel (Ni), copper (Cu), zinc $(\mathrm{Zn})$, arsenic (As), cadmium (Cd), lead (Pb) and mercury ( $\mathrm{Hg}$ ) contents in 16 fish species (155 samples) and sediments of their habitats were analyzed. In general, the concentrations of these eight metal(loid)s in most fish samples are lower than the guideline levels and legal limits, and the $\mathrm{Pb}$ and $\mathrm{Hg}$ level in $0.65 \%$ of samples were exceeded the quality standards in China. The $\mathrm{Cr}, \mathrm{As}, \mathrm{Cd}$ and $\mathrm{Pb}$ levels in most fish samples are less than those reported in previous studies. Nonetheless, Hg levels in these fish samples are significantly higher than those reported in previous studies conducted in other regions. Different from the wild fish, significant positive correlations are found between $\mathrm{Cr}$, Ni, As and $\mathrm{Cd}$ concentrations in cultured fish and those in pond sediment $(P<0.05)$, which might be due to the closed static water environment and concentrated feeding operations. $\mathrm{Cu}, \mathrm{Zn}$, As and $\mathrm{Hg}$ concentrations differed significantly among wild species, while $\mathrm{Cu}$ and $\mathrm{Zn}$ concentrations differed significantly among cultured species $(P<0.05)$, which might be because of the different feeding and foraging habitats. The target hazard quotients (THQs) at high exposure levels of target metal(loid)s in the studied fish were below 1 (except for $\mathrm{Hg}$ ), and the carcinogenic risk indices of $\mathrm{Cr}$, As, and $\mathrm{Cd}$ were less than $10^{-4}$. The levels of metal(loid)s (except for $\mathrm{Hg}$ ) in the studied fishes fell within an acceptable range, but more attention should be paid to the potential carcinogenic risks.
\end{abstract}

\section{Introduction}

Increasing human activities have caused the increasing release of heavy metals into the hydrosphere. ${ }^{\mathbf{1 , 2}}$ This is especially the case for the surface water, which turns into a sink for heavy metals from the wastes (e.g., emission, wastewater and waste solids). Studies have found high levels of heavy metals being released into freshwater ecosystems because of the effects of urbanization and industrialization. ${ }^{3}$ Some rivers and lakes have encountered different levels of ecological risks due to heavy metal pollution. ${ }^{4-7}$ Fishes exposed to elevated metal levels can absorb the bioavailable metals (e.g., cadmium (Cd), nickel (Ni), lead $(\mathrm{Pb})$, and mercury $(\mathrm{Hg}))$ directly from an aquatic environment $^{8}$ and regulate metal concentrations where bioaccumulation will occur in tissues to some extent. ${ }^{9}$ Researchers have found evidence that supports the biomagnification of

${ }^{a}$ State Key Laboratory of Urban Water Resource and Environment, Harbin Institute of Technology, 150090, Harbin, Heilongjiang, China. E-mail: qiuweihit@126.com ${ }^{b}$ Heilongjiang River Fisheries Research Institute, Chinese Academy of Fishery Sciences, 150070, Harbin, Heilongjiang, China

${ }^{c}$ School of Municipal \& Environmental Engineering, Harbin Institute of Technology, 150090, Harbin, Heilongjiang, China some heavy metals (e.g., chromium $(\mathrm{Cr})$, copper $(\mathrm{Cu})$, arsenic (As), $\mathrm{Cd}, \mathrm{Pb}$ and $\mathrm{Hg}$ ) with trophic levels in marine and freshwater ecosystems. ${ }^{\mathbf{1 0 - 1 4}}$ Bioaccumulation and biomagnification can cause heavy metal burdens in the muscle tissues of fish to increase ${ }^{\mathbf{8}, 15}$ Excessive levels of heavy metals could harm aquatic organisms, causing the escalation of heavy metal levels in fish tissues to dangerous levels. ${ }^{16}$ The consumption of polluted fish could potentially result in serious food poisoning among the general public.

In general, heavy metal levels in a fish are related to its living environment, feeding behavior and foraging habitats. ${ }^{17,18}$ There are numerous studies on the relationship between heavy metal pollution in the environment and in fish. For instance, sediment acts as an important sink for heavy metals, which affects the heavy metal bioconcentration by affecting bioavailability. ${ }^{19}$ Because of the biogeochemical characteristics and pathways of trophic transfer, the metal burdens in food web components are different, which lead to the difference in individual fish taxa by functional feeding groups. ${ }^{\mathbf{2 0 , 2 1}}$ Previous studies have suggested that the foraging habitat is a strong predictor for variations in heavy metal concentrations in fish. ${ }^{21}$ While heavy metal contamination of freshwater and marine biota in China has been well described, ${ }^{\mathbf{1 0 , 1 2 , 1 7 , 1 8 , 2 2}}$ such investigations are rather 
limited in Northeast China. Some heavy metals (i.e., As, Cd, $\mathrm{Pb}$ and $\mathrm{Hg}$ ) are of major environmental concern as they can cause severe health implications for humans and other living organisms. Moreover, some elements (e.g., $\mathrm{Cr}, \mathrm{Ni}, \mathrm{Cu}$ and zinc ( $\mathrm{Zn})$ ) that play essential roles in life activities become toxic in excess amounts.

Northeast China is a water-rich area with satisfactory water resource conditions and long fishing history, especially the Amur River basin, which contains a rich freshwater ecosystem with various fish species from the frigid-zone, temperate zone and even the tropical zone. In Northeast China, aquatic environments such as rivers, lakes, artificial reservoirs and ponds provide all types of aquaculture. However, many major cities and chemical enterprises in Northeast China are located near rivers and lakes, where the released waste threatens these aquatic ecosystems. Recently, two serious environmental contamination accidents have occurred in the Songhua River, which is the third-largest river in China and one of the biggest tributaries of the Amur River. ${ }^{23,24}$ Studies have found elevated heavy metal concentrations in the water and sediment in some rivers and lakes in Northeast China. ${ }^{25-27}$ Studies have been conducted to investigate the trace elements in the tissues of fish from fish farms ${ }^{28}$ and individual rivers or areas in Northeast China. ${ }^{29}$ Nonetheless, little is known about the heavy metal levels in fish from Northeast China, particularly for various species with different feeding habits, and the relationship between heavy metals and the environment.

This study aims to develop a large-scale analysis to compare eight metal(loid) levels (including $\mathrm{Cr}, \mathrm{Ni}, \mathrm{Cu}, \mathrm{Zn}, \mathrm{As}, \mathrm{Cd}, \mathrm{Pb}$ and $\mathrm{Hg}$ ) in fish from different water types in Northeast China, investigate the relationship between heavy metals and the environment as well as evaluate the potential health risks associated with fish consumption.

\section{Materials and methods}

\subsection{Study area and sample collection}

In the period from May to September of 2015, a total of 155 fish samples representing 16 species were randomly collected from various fishery areas, including the trunk stream of Amur River (Amur R.), Songhua River (Songhua R.), Ussuri River (Ussuri R.), Second Songhua River (SSonghua R.) and Nen River (Nen R.), Chagan Lake (CGL), Songhua Lake (SHL), Xingkai Lake (XKL), Jingpo Lake (JPL) and some ponds at city sites (Harbin, Jiamusi, Zhaodong, Changchun, Jilin and Songyuan) (Fig. 1). Sediment samples were also collected from the same localities. Basic biological information on the sampled fish, e.g., species, number, feeding habits, age, total length and body weights, are displayed in Table 1. The dorsal muscle tissues of fish samples were taken and homogenized. Fish samples were put into a clean polythene bag and immediately stored at $-20^{\circ} \mathrm{C}$ before the subsequent heavy metal analysis. A total of 235 sediment samples were extracted from the upper layer $(0-10 \mathrm{~cm})$ of the sampling sites (five sampling sites in each sampling area) using polyvinyl chloride corers. The sediment samples were immediately mixed and $2.0 \mathrm{~kg}$ were reserved in a hermetic bag and stored at $4{ }^{\circ} \mathrm{C}$ before arriving at the laboratory.

\subsection{Analysis of metal(loid)s}

In a report by Qin et al., ${ }^{28}$ target metal(loid)s except $\mathrm{Hg}$ were determined using an inductively-coupled plasma mass spectrometer (ICP-MS, Agilent 7500cx, USA) equipped with an octopole reaction system (ORS). For fish muscle (epaxial muscle on the dorsal surface without skin and backbone) analysis, each $1.0 \mathrm{~g}$ of the homogenized sample was digested and mixed using an automatic microwave system with a mixture of $\mathrm{HNO}_{3}: \mathrm{H}_{2}$ $\mathrm{O}_{2}$ : Milli-Q water $=5: 2: 1$. After cooling, the sample was diluted with Milli-Q water (Milli-Pore Co., USA; resistivity, 18.2 $\mathrm{M} \Omega \mathrm{cm}$ ), stored at $4{ }^{\circ} \mathrm{C}$ temperature, and analyzed within $24 \mathrm{~h}$. For sediment samples, each $0.1 \mathrm{~g}$ of dried and powdered sediment sample was digested with mixed acids $\left(\mathrm{HClO}_{4}: \mathrm{HF}: \mathrm{HCl}\right.$ $=1: 5: 1$ ) in an automatic microwave digestion system. After cooling, the sample was distilled to dryness and diluted with Milli-Q water. For analysis of the $\mathrm{Hg}$ content, an Automatic Mercury Analyzer Hydra IIC (Teledyne Leeman Labs Hudson, $\mathrm{NH}$, USA) was used.

\section{$2.3 \mathrm{QA} / \mathrm{QC}$}

Nitric acid, peroxide hydrogen and hydrochloric acid utilized in this study were all guaranteed reagents. Glassware used in this study were all immersed in $10 \%(\mathrm{~V} / \mathrm{V})$ of nitric acid overnight, washed three times with Milli-Q water, and then dried in an oven. The certified reference solution ICP Standards of $\mathrm{Cr}, \mathrm{Ni}$, $\mathrm{Cu}, \mathrm{Zn}, \mathrm{As}, \mathrm{Cd}$ and $\mathrm{Pb}\left(1000 \mu \mathrm{g} \mathrm{mL^{-1 }}\right)$ were all purchased from the National Analysis and Testing Center for Nonferrous Metals \& Electronic Materials. Yellow croaker (GBW08573), GSS-3 (GBW-07403) and GSS-5 (GBW-07405) were utilized as processing Certified Reference Materials for analysis validation. The results were in good agreement with the certified values and recoveries ranged from $86.5 \%$ to $104.3 \%$. Analytical blanks were prepared in parallel in the same way as the samples for evaluating the possibility of pollution and background interference. For fish samples, the limits of detection (LOD, $\mathrm{mg} \mathrm{kg}^{-1}$ wet weight) were the following: $\mathrm{Cr} 0.005$, Ni $0.010, \mathrm{Cu} 0.008, \mathrm{Zn}$ 0.015, As 0.003, Cd 0.001, Pb 0.005, and $\mathrm{Hg} 0.001$. For sediment samples, the limits of detection (LOD, $\mathrm{mg} \mathrm{kg}^{-1}$ wet weight) were the following: $\mathrm{Cr} 0.180$, Ni 0.100, Cu 0.100, $\mathrm{Zn} \mathrm{0.700,} \mathrm{As} \mathrm{0.190,}$ $\mathrm{Cd}$ 0.003, $\mathrm{Pb} 0.040$, and $\mathrm{Hg} 0.001$.

\subsection{Risk assessment}

2.4.1 Estimated daily intake (EDI). The estimated daily intake (EDI) for each heavy metal element (i.e., $\mathrm{Cr}, \mathrm{Ni}, \mathrm{Cu}, \mathrm{Zn}$, $\mathrm{As}, \mathrm{Cd}, \mathrm{Pb}$, and $\mathrm{Hg}$ ) was calculated based on the following equation:

$$
\mathrm{EDI}=\frac{\mathrm{FIR} \times C_{\mathrm{i}}}{\mathrm{BW}}
$$

where FIR is the food ingestion rate of fish and fish products ( $\mathrm{g}$ per person per day, wet weight), $C_{\mathrm{i}}$ is the average concentration of a single heavy metal in a fish muscle $\left(\mathrm{mg} \mathrm{kg}^{-1}\right)$, and BW is the average body weight of an adult. ${ }^{30}$ For adults in rural and urban areas of China, the food ingestion rate of fish was $23.7 \mathrm{~g}$ per person per day. ${ }^{31}$ The average body weight of an adult is $60 \mathrm{~kg}$. If the element concentration was lower than the limit of detection 


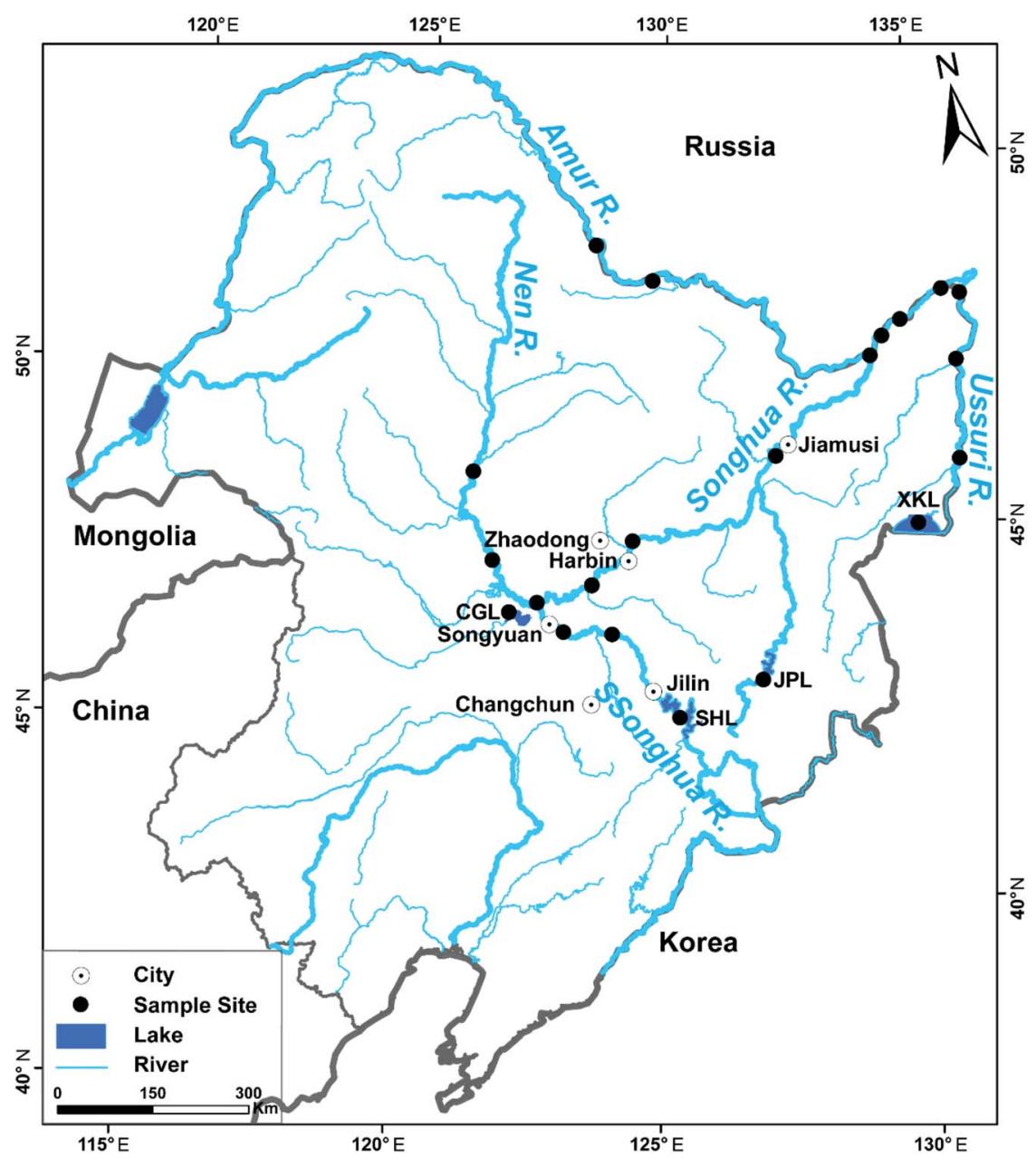

Fig. 1 Fish sampling locations in the study area.

(LOD), the value would be taken as half of the respective detection limits $\left(\frac{1}{2}\right.$ LOD).

2.4.2 Non-carcinogenic risk. To express the potential noncarcinogenic risk of fish samples in this study, the target hazard quotient (THQ) was utilized. The THQ is equal to the ratio of an EDI value to an oral reference dose (RfD, $\mu \mathrm{g}$ per $\mathrm{kg}$ per day) value. The RfD was established by the United States Environmental Protection Agency. ${ }^{32}$ The THQ for each analyzed metal ( $\mathrm{Cr}, \mathrm{Ni}, \mathrm{Cu}, \mathrm{Zn}, \mathrm{As}, \mathrm{Cd}, \mathrm{Pb}$, and $\mathrm{Hg}$ ) was calculated by usinf the following formula:

$$
\mathrm{THQ}=\frac{\mathrm{EDI}}{\mathrm{RfD}}
$$

When the THQ value is less than one, there should be no obvious non-carcinogenic risks for the exposed population. Otherwise, the exposed population would experience adverse health risks. Such concerns would further increase with a higher THQ value.

2.4.3 Carcinogenic risk. The carcinogenic risk index (CRI) is used for evaluating the potential carcinogenic risks of fish consumption. $^{33}$ The CRIs for elements $\mathrm{Cr}$, As, and $\mathrm{Cd}$ are calculated as follows:

$$
\mathrm{CRI}_{\mathrm{i}}=\frac{\mathrm{FIR} \times E_{\mathrm{F}} \times E_{\mathrm{D}}}{\mathrm{BW} \times T_{\mathrm{A}}} \times \mathrm{SF}_{\mathrm{i}} \times C_{\mathrm{i}}
$$

where $E_{\mathrm{F}}$ is the exposure frequency (365 d per year), $E_{\mathrm{D}}$ is the exposure duration (70 year), $T_{\mathrm{A}}$ is the averaging time $\left(365 \times E_{\mathrm{D}}\right.$ d), and $\mathrm{SF}_{\mathrm{i}}$ is the oral slope factor $\left(\left(\mathrm{mg} \mathrm{kg}{ }^{-1} \mathrm{~d}^{-1}\right)^{-1}\right)$ for a single heavy metal. The oral intake of carcinogenic slope factors for $\mathrm{Cr}$, As, and Cd are 0.50, 0.38 and 1.50, respectively. When the CRI value is less than $10^{-6}$, the compound is safe for humans. When the CRI value is between $10^{-6}$ and $10^{-4}$, there are potential carcinogenic risks to the exposed population. When the CRI value is more than $10^{-4}$, the exposed people would encounter excess carcinogenic risk.

\subsection{Statistical analysis}

Statistical analysis was performed using the SPSS software (IBM SPSS statistics for Windows, version 20.0; SPSS Inc., Chicago, IL). The Mann-Whitney test was performed to compare the metal(loid)s concentration in fish samples captured from natural waters and that from aquaculture ponds. Metal(loid) concentrations in fish and sediment samples were $\log (x)$ transformed and their relationships were expressed using the Pearson correlation test. The linear regression analyses were 
Table 1 Basic biological information of fish in this study ${ }^{a}$

\begin{tabular}{|c|c|c|c|c|c|c|}
\hline Scientific name & English name & $n$ & Feeding habits & Foraging habitats & The total length $(\mathrm{cm})$ & Body weights (kg) \\
\hline Hypomesus olidus & Pond smelt & 1 & Omnivory & Pelagic fishes & 10.20 & 0.0085 \\
\hline Esox reicherti & Amur pike & 6 & Sarcophagy & Pelagic fishes & $\begin{array}{l}50.60 \pm 2.40 \\
(47.00-55.00)\end{array}$ & $\begin{array}{l}0.64 \pm 0.14 \\
(0.52-0.91)\end{array}$ \\
\hline Leuciscus waleckii & Amur ide & 3 & Omnivory & Pelagic fishes & $\begin{array}{l}23.90 \pm 3.60 \\
(19.00-29.00)\end{array}$ & $\begin{array}{l}0.14 \pm 0.093 \\
(0.035-0.28)\end{array}$ \\
\hline Ctenopharyngodon idellus & Grass carp & 19 & Herbivority & Middle-lower layers fishes & $\begin{array}{l}53.00 \pm 11.20 \\
(38.00-72.00)\end{array}$ & $\begin{array}{l}1.93 \pm 1.14 \\
(0.71-4.23)\end{array}$ \\
\hline Hemibarbus labeo & Barbell steed & 2 & Omnivory & Bottom fishes & $\begin{array}{l}26.00 \pm 4.90 \\
(22.50-29.50)\end{array}$ & $\begin{array}{l}0.16 \pm 0.09 \\
(0.095-0.23)\end{array}$ \\
\hline Hemibarbus maculatus & Spotted steed & 1 & Omnivory & Middle-lower layers fishes & 28.00 & 0.22 \\
\hline Saurogobio dabryi & Chinese lizard gudgeon & 1 & Omnivory & Middle-lower layers fishes & 13.70 & 0.031 \\
\hline Erythroculter ilishaeformis & Topmouth culter & 7 & Sarcophagy & Pelagic fishes & $\begin{array}{l}54.90 \pm 8.50 \\
(42.00-69.00)\end{array}$ & $\begin{array}{l}1.23 \pm 0.46 \\
(0.71-2.06)\end{array}$ \\
\hline Erythroculter mongolicus & Mongolian redfin & 1 & Sarcophagy & Pelagic fishes & 24.50 & 0.22 \\
\hline Cyprinus carpio & Common carp & 39 & Omnivory & Bottom fishes & $\begin{array}{l}42.80 \pm 7.40 \\
(29.00-61.00)\end{array}$ & $\begin{array}{l}1.29 \pm 0.87 \\
(0.32-4.40)\end{array}$ \\
\hline Carassius auratus & Crucian carp & 36 & Omnivory & Bottom fishes & $\begin{array}{l}21.80 \pm 5.50 \\
(8.80-29.00)\end{array}$ & $\begin{array}{l}0.22 \pm 0.14 \\
(0.019-0.47)\end{array}$ \\
\hline Hypophthalmichthys molitrix & Silver carp & 11 & Filter feeder (zooplankton, phytoplankton) & Pelagic fishes & $\begin{array}{l}47.30 \pm 11.90 \\
(26.00-61.00)\end{array}$ & $\begin{array}{l}1.22 \pm 0.86 \\
(0.15-3.65)\end{array}$ \\
\hline Aristichthys nobilis & Bighead carp & 12 & Filter feeder (zooplankton, phytoplankton) & Pelagic fishes & $\begin{array}{l}51.20 \pm 9.40 \\
(33.00-64.00)\end{array}$ & $\begin{array}{l}2.16 \pm 1.13 \\
(0.45-4.19)\end{array}$ \\
\hline Pseudobagrus fulvidraco & Yellow catfish & 2 & Omnivory & Bottom fishes & $\begin{array}{l}15.10 \pm 3.40 \\
(12.70-17.50)\end{array}$ & $\begin{array}{l}32.0 \pm 2.83 \\
(30.0-34.0)\end{array}$ \\
\hline Parasilurus asotus & Sheatfish & 13 & Sarcophagy & Bottom fishes & $\begin{array}{l}37.00 \pm 9.40 \\
(25.00-50.00)\end{array}$ & $\begin{array}{l}0.41 \pm 0.36 \\
(0.10-1.38)\end{array}$ \\
\hline Protosalanx hyalocranius & Clearhead icefish & 1 & Sarcophagy & Pelagic fishes & 14.50 & 0.025 \\
\hline
\end{tabular}

performed to compare the relationships between metal(loid)s concentration in fish and sediment samples. One-way ANOVA followed by the Dunn's test was performed to determine whether differences in metal(loid) concentrations in different fish species were significant. The statistical significance level was acceptable at $p<0.05$. All sample values were expressed as $\mathrm{mg} \mathrm{kg}^{-1}$ wet weight.

\section{Results and discussion}

\subsection{Levels of eight metal(loid)s in fish muscles}

The levels of eight metal(loid)s (wet weight) in fish muscles are shown in Table 2 . The essential elements ( $\mathrm{Cu}$ and $\mathrm{Zn}$ ) are found in all the samples, while the elements that are essential but toxic in excess amounts ( $\mathrm{Cr}$ and $\mathrm{Ni}$ ) and the detection rates of toxic elements (As, $\mathrm{Cd}, \mathrm{Pb}$ and $\mathrm{Hg}$ ) are 33.55\%, 19.35\%, 97.42\%, $48.39 \%, 70.97 \%$ and $74.19 \%$, respectively. The metal concentration of $\mathrm{Zn}$ is the highest $\left(7.97 \pm 6.05 \mathrm{mg} \mathrm{kg}^{-1}\right)$, followed by $\mathrm{Cu}\left(0.27 \pm 0.13 \mathrm{mg} \mathrm{kg}^{-1}\right), \mathrm{Hg}\left(0.079 \pm 0.14 \mathrm{mg} \mathrm{kg}^{-1}\right)$, As $(0.052$ $\left.\pm 0.054 \mathrm{mg} \mathrm{kg}^{-1}\right)$ and $\mathrm{Pb}\left(0.034 \pm 0.074 \mathrm{mg} \mathrm{kg}^{-1}\right)$. In contrast, other heavy metals ( $\mathrm{Cr}, \mathrm{Ni}$ and $\mathrm{Cd}$ ) are of minor importance because of low concentrations $\left(<0.02 \mathrm{mg} \mathrm{kg}^{-1}\right)$. None of the fish samples have $\mathrm{Cr}, \mathrm{Cu}$ and $\mathrm{Cd}$ levels above the guideline levels and legal limits shown in Table $2 .^{30,34-37}$ The concentrations of $\mathrm{As}, \mathrm{Pb}$ and $\mathrm{Hg}$ are in the range of $\mathrm{ND}-0.39 \mathrm{mg} \mathrm{kg}^{-1}, \mathrm{ND}-0.70 \mathrm{mg}$ $\mathrm{kg}^{-1}$ and ND-0.82 $\mathrm{mg} \mathrm{kg}^{-1}$, respectively. Total As levels in some of the fish muscle samples exceed the inorganic arsenic criterion quality standard in $\mathrm{China}^{34}$ of $0.10 \mathrm{mg} \mathrm{kg}^{-1}$ and overall, $10.97 \%$ (17 fish muscle samples) were above the criterion. According to the hypothesis, inorganic arsenic levels could be estimated using a value of $10 \%$ of total As. The estimated concentration of inorganic arsenic for the 17 fish muscle samples are all below the criterion of $0.10 \mathrm{mg} \mathrm{kg}^{-1}$. Nonetheless, the $\mathrm{Pb}$ level of one fish muscle sample exceeds the maximum levels set by the quality standard in China and DHO action levels (of $0.50 \mathrm{mg} \mathrm{kg} \mathrm{kg}^{-1}$ wet weight); and $1.94 \%$ (3 samples) and $2.58 \%$ (4 samples) of the samples are above the Commission Regulation (EC) $\left(0.30 \mathrm{mg} \mathrm{kg}^{-1}\right)$ FAO guidelines $\left(0.20 \mathrm{mg} \mathrm{kg}{ }^{-1}\right)$, respectively. ${ }^{30,36}$ Total $\mathrm{Hg}$ levels in $2.58 \%$ (4 samples) of the samples were greater than $0.50 \mathrm{mg} \mathrm{kg}^{-1}$, but only one sample was above the methylmercury criterion set by the quality standard in China because of the maximum level for predatory fish $\left(1.0 \mathrm{mg} \mathrm{kg}^{-1}\right)$. Based on the assumption that $75 \%$ of total mercury in fish was methylmercury, ${ }^{38}$ the estimated methylmercury value of the Hg-excess sample still exceeded the criterion of $0.50 \mathrm{mg} \mathrm{kg}^{-1}$.

The results presented here are comparable to the studies conducted elsewhere, which also reported $\mathrm{Cu}$ and $\mathrm{Zn}$ to be the most abundant compounds among detected chemical elements (Table 3). ${ }^{17,18,39-41}$ The concentrations of $\mathrm{Cr}, \mathrm{As}, \mathrm{Cd}$ and $\mathrm{Pb}$ in most of the samples are either less than previous studies $^{\mathbf{1 0 , 1 1 , 2 2 , 3 9 , 4 0 , 4 2}}$ or undetected. $\mathrm{Hg}$ concentrations of fish in this study are higher than those from the Yellow River Estuary, ${ }^{\mathbf{1 0}}$ 
Table 2 Descriptive statistics of eight metal(loid)s $\left(\mathrm{mg} \mathrm{kg}^{-1}\right.$ wet weight) in fish muscle samples $(n=155)^{a}$

\begin{tabular}{|c|c|c|c|c|c|c|c|c|c|c|c|}
\hline \multirow[b]{2}{*}{ Heavy metals } & \multirow[b]{2}{*}{ Min. } & \multirow[b]{2}{*}{ Max. } & \multirow[b]{2}{*}{ Mean } & \multirow[b]{2}{*}{ Standard deviation } & \multirow[b]{2}{*}{ Median } & \multirow[b]{2}{*}{ Detection rate $(\%)$} & \multicolumn{4}{|c|}{ Maximum levels (MLs) for heavy metals in fish } & \multirow[b]{2}{*}{ Over-limit ratio $^{b}(\%)$} \\
\hline & & & & & & & $\begin{array}{l}\text { Quality standard } \\
\text { in China }\end{array}$ & $\begin{array}{l}\text { Commission regulation } \\
\text { (EC) }\end{array}$ & FAO & DHO & \\
\hline $\mathrm{Cr}$ & $\mathrm{ND}^{c}$ & 0.49 & 0.018 & 0.048 & 0.019 & 33.55 & $2.00^{d}$ & & & & 0 \\
\hline $\mathrm{Ni}$ & ND & 0.78 & 0.019 & 0.069 & 0.039 & 19.35 & & & & & \\
\hline $\mathrm{Cu}$ & 0.067 & 0.97 & 0.27 & 0.13 & 0.25 & 100.00 & $50^{e}$ & & 30 & & 0 \\
\hline $\mathrm{Zn}$ & 2.49 & 51.38 & 7.97 & 6.05 & 5.94 & 100.00 & & & 30 & & \\
\hline As & ND & 0.39 & 0.052 & 0.054 & 0.039 & 97.42 & $0.10^{d}$ & & & 3.00 & 10.97 \\
\hline $\mathrm{Cd}$ & ND & 0.009 & 0.0012 & 0.0013 & 0.0010 & 48.39 & $0.10^{d}$ & 0.05 & 0.05 & 1.00 & 0 \\
\hline $\mathrm{Pb}$ & ND & 0.70 & 0.034 & 0.074 & 0.024 & 70.97 & $0.50^{d}$ & 0.30 & 0.20 & 0.50 & 0.65 \\
\hline $\mathrm{Hg}$ & ND & 0.82 & 0.079 & 0.14 & 0.057 & 74.19 & $0.50 / 1.00^{d}$ & 0.50 & $0.50 / 1.00^{f}$ & $0.50 / 1.00^{f}$ & 0.65 \\
\hline
\end{tabular}

${ }^{a} n$ means the number of muscle samples. ${ }^{b}$ According to the quality standard in China. ${ }^{c}$ ND: Not detected, means the value is lower than the limit of detection. Concentrations less than the LOD were set to $\frac{1}{2}$ LOD for statistical analysis. ${ }^{d}$ GB $2762-2017$ National Food Safety Standard Maximum

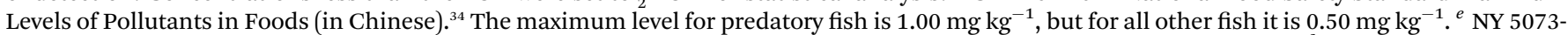
2006 Limited Quantity of Poisonous and Harmful Contents of the National Pollution-Free Aquatic Products (in Chinese). ${ }^{35} f$ The maximum level for predatory fish including swordfish is $1.00 \mathrm{mg} \mathrm{kg} \mathrm{k}^{-1}$ but for all other fish and processed fish, it is $0.50 \mathrm{mg} \mathrm{kg}^{-1}$.

South China Sea, ${ }^{\mathbf{2}}$ East China $\mathrm{Sea}^{\mathbf{4 3}}$ and Yangtze River, ${ }^{\mathbf{4 4}}$ confirming heavy metal pollution in the waters of Northeast China.

\subsection{Effect of environment on the metal(loid) levels in fish}

The target metal(loid) concentrations in wild fish from natural waters and cultured fish from aquaculture ponds are compared in Fig. 2. The Mann-Whitney test of the $\mathrm{Ni}, \mathrm{Cu}$ and $\mathrm{Zn}$ concentrations in fish showed little differences between the means of both separate fish samples $(\alpha=0.05)$. The mean concentrations of $\mathrm{Cr}$ in the cultured fish were higher than those in the wild fish and differed significantly among the water types $(P=0.003)$. The accumulation of As was relatively high $(P=$ 0.017 ) in wild fish from rivers and lakes as compared to those from ponds. Significantly higher $\mathrm{Cd}$ and $\mathrm{Hg}$ levels $(P<0.0001)$ were found in wild fish as compared to those in the cultured fish. The concentration of $\mathrm{Pb}$ was much higher $(P<0.0001)$ in cultured fish than that in wild fish. The detection frequencies of these toxic elements (As, $\mathrm{Cd}$ and $\mathrm{Hg}$ ) in wild fish $(97.78 \%$, $61.11 \%$ and $92.22 \%$, respectively) were higher than those in cultured fish $(96.92 \%, 32.31 \%$ and 49.23 , respectively). The detection frequency of $\mathrm{Pb}$ in wild fish was lower than that in cultured fish (52.22\% and 96.92\%, respectively). Among the essential elements (Cr, Ni, $\mathrm{Cu}$ and $\mathrm{Zn}$ ), $\mathrm{Cu}$ and $\mathrm{Zn}$ were detected in all the samples. However, $\mathrm{Cr}$ and $\mathrm{Ni}$ detection rates $(27.78 \%$ and $15.56 \%$ ) in wild fish were lower than in cultured fish (47.69\% and $24.62 \%$ ).

The relationship between metal(loid) concentrations in fish and in their living environment is shown in Fig. 3. The target metal(loid) concentrations in wild fish are not correlated to those in the sediment of their living environment (except for $\mathrm{Cd}$ ). Cd concentrations in wild fish samples were positively correlated to Cd levels in the sediments of nature water $\left(R^{2}=0.081, P=0.012\right)$. Positive correlations were observed between $\mathrm{Cr}, \mathrm{Ni}$, As and Cd concentrations in the cultured fish and in pond sediment $\left(R^{2}=0.099, R^{2}=0.070\right.$, $R^{2}=0.038$ and $R^{2}=0.145$, respectively, $P<0.05$ for all tests). However, correlations between $\mathrm{Cu}, \mathrm{Zn}, \mathrm{Pt}$ and $\mathrm{Hg}$ concentrations in cultured fish and those in pond sediment were relatively weak $\left(R^{2}=0.022, R^{2}=0.044, R^{2}=0.025\right.$ and $R^{2}$ $=0.004$, in order, $P>0.05$ for all tests).

Metal(loid)s in the fish samples analyzed in this study are closely related to their living environment. ${ }^{10}$ In the closed static water environment, cultured fish can absorb the essential elements $\mathrm{Cr}, \mathrm{Ni}, \mathrm{Cu}$ and $\mathrm{Zn}$ from aquaculture feed, which results in higher levels and detection rates. This may explain why $\mathrm{Cr}$ and Ni levels in cultured fish tend to correlate with those in the pond sediment (mainly composed of feed bait, excrement, plankton particles and other suspended matter). Ponds investigated in this study usually use groundwater or clean spring water as the aquaculture water source. Thus, the significant relationship between the As and Cd concentrations in cultured fish and in pond sediment may indicate that As and $\mathrm{Cd}$ in cultured fish originate from the aquaculture feed. The potential routes of metal(loid)s entering a fish include food and non-food particle intake, surface absorption by fish tissues (gill, skin and body mucus) and oral consumption of water. ${ }^{8,45}$

Relative to wild fish, the higher detection rates and levels of $\mathrm{Pb}$ in cultured fish are the results of compounded effects from the aquaculture feed and water environment. Metal(loid)s in fish can reflect the water environmental pollution to a certain extent. ${ }^{10,14}$ The detection frequency of As in cultured fish was similar to that in fish from natural water, while the As concentration was significantly lower than in wild fish, which indicated As-pollution in natural waters. The Songhua River in Northeastern China is one of the representative $\mathrm{Hg}$-polluted rivers in China. ${ }^{23}$ About $149.8 \mathrm{t}$ of $\mathrm{Hg}$ from the Jilin chemical plant had been directly discharged into the Songhua River in 1958-1971. Studies on $\mathrm{Hg}$ pollution of fish and sediment in the Songhua River and health concerns of local residents have been uninterrupted over the past 40 years..$^{25,46,47}$ Recent research showed that the T-Hg pollution level of the Second Songhua River was moderate to severe with high ecological risk, and the pollution levels in the main stream of the Songhua River were 


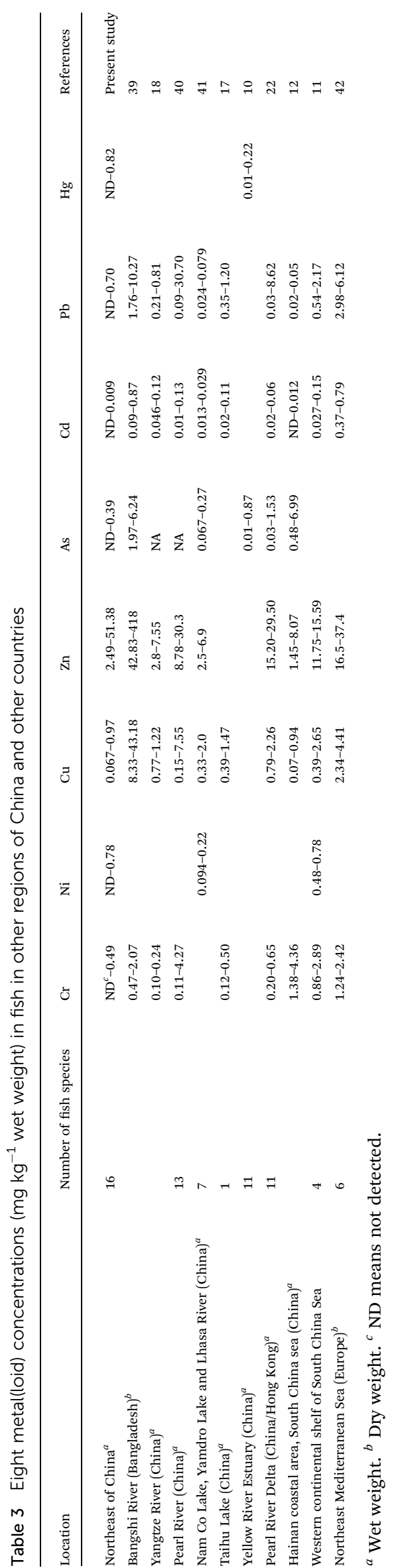

mild with low ecological risk. ${ }^{26}$ As mentioned above, the $\mathrm{Hg}$ levels in wild fish in this study are significantly higher than in the cultured fish $(P<0.0001)$, confirming the high level of $\mathrm{Hg}$ pollution and the potential ecological risk of natural waters.

\subsection{Effects of different species on the metal(loid) levels in fish}

The mean concentrations of eight metal(loid)s for each fish species from Northeast China are displayed in Table 4. Because of the different fish species and environmental factors, the data for wild and cultured fishes were analyzed separately. For the wild fish, because the sample sizes of Ctenopharyngodon idellus $(n=2)$, Erythroculter mongolicus $(n=1)$, Saurogobio dabryi $(n=1)$, Hemibarbus labeo $(n=2)$, Leuciscus waleckii $(n=3)$, Pseudobagrus fulvidraco $(n=2)$ and Hemibarbus maculatus $(n=1)$ were small, their data were not included in the further analysis for post hoc testing. The levels of $\mathrm{Pb}, \mathrm{Zn}$, As and $\mathrm{Hg}$ significantly differed among the wild species $(P=0.0067$, $P<0.0001, P=0.001$ and $P=0.0005$, in order). Significantly higher $\mathrm{Cu}$ levels were found in wild Carassius auratus as compared to Esox reicherti and Parasilurus asotus ( $P$ $<0.05$ for post hoc tests). The level of $\mathrm{Zn}$ in wild Carassius auratus was significantly higher than in wild Esox reicherti, Hypophthalmichthys molitrix, Parasilurus asotus and Aristichthys nobilis, and was high in Cyprinus carpio relative to Hypophthalmichthys molitrix $(P<0.05)$. The toxic elements As and $\mathrm{Hg}$ in fish need to be paid more attention. Significantly higher As levels were found in wild Carassius auratus, Hypophthalmichthys molitrix and Cyprinus carpio compared to those in Parasilurus asotus $(P<0.05)$. Mercury was found to be high in Esox reicherti as compared to that in Carassius auratus, Aristichthys nobilis and Cyprinus carpio $(P=0.007, P=0.016$ and $P=0.006$, respectively). For the cultured fish, since the sample sizes of Hypophthalmichthys molitrix $(n=1)$ and Aristichthys nobilis $(n=$ 3) were small, they were excluded from the post hoc test. Only $\mathrm{Cu}$ and $\mathrm{Zn}$ significantly differed among the cultured species $(P=0.0005$ and $P=0.030$, respectively). Much higher $\mathrm{Cu}$ levels were found in cultured Carassius auratus and Ctenopharyngodon idellus as compared to those in Cyprinus carpio $(P=0.0016$ and $P=0.0046$, respectively). Zinc levels were obviously higher in cultured Ctenopharyngodon idellus as compared to that in Cyprinus carpio $(P=$ 0.039).

Fish species are one of the most important drivers for metal(loid) accumulation, probably because of different feeding habits and foraging habitats of the studied fish. Dietary habits would affect the concentrations of the toxic elements $\mathrm{As}$ and $\mathrm{Hg}$ in fish from Northeast China. Relatively high As levels are observed in wild filter-feeding (Hypophthalmichthys molitrix and Aristichthys nobilis) and omnivory (Carassius auratus and Cyprinus carpio) fish, while the wild sarcophagi fish (Parasilurus asotus and Erythroculter ilishaeformis) had lower As concentration. 


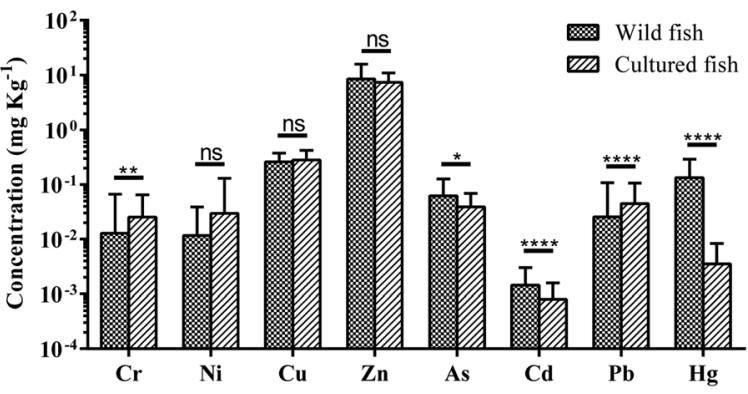

Fig. 2 The target metal(loid) concentrations in wild fish from natural waters and cultured fish from aquaculture ponds.

Differences in As levels among wild fish species could be due to trophic transfer in the food web/sources. ${ }^{48}$ The Hypophthalmichthys molitrix and Aristichthys nobilis were strictly planktivorous and were expected to acquire As from small plankton and zooplankton. Carassius auratus and Cyprinus carpio do not feed exclusively on the small plankton and zooplankton but also feed on benthic animals. Parasilurus asotus and Erythroculter ilishaeformis are carnivorous and feed on small fishes. Chen and Folt ${ }^{20}$ reported that As could be elevated in lower trophic levels, and lower trophic feeders in the fish feeding strategy experiment would have higher metal burdens (planktivores > omnivores and piscivores). Notably, higher As is found in the muscle of the omnivorous fish, Carassius auratus, which could be due to both the foraging habitat and feeding habits. Similar to previous studies, the current study has found that the $\mathrm{Hg}$ concentration in wild sarcophagi fish is higher than that in omnivores and filter-feeding. Many studies also reported evidence of the biomagnification and bioaccumulation of mercury with trophic levels. ${ }^{13,15,49}$ Particularly, total mercury burdens in muscle tissue are a result of biomagnification through the food web rather than bioaccumulation. ${ }^{15}$

\subsection{Human health risk assessment of metal(loid)s via fish consumption}

Oral reference dose (RfDs) values for $\mathrm{Ni}, \mathrm{Cu}, \mathrm{Zn}$ and $\mathrm{Cd}$ are 20, 40, 300 and $1 \mu \mathrm{g}$ per kg per day, respectively. ${ }^{32}$ The $\mathrm{RfD}$ of $\operatorname{Cr}(\mathrm{v})(3.0 \mu \mathrm{g}$ per $\mathrm{kg}$ per day), inorganic arsenic $(0.3 \mu \mathrm{g}$ per $\mathrm{kg}$ per day) and methylmercury ( $0.1 \mu \mathrm{g}$ per $\mathrm{kg}$ per day) are taken to represent that of $\mathrm{Cr}$, As, and $\mathrm{Hg}$, respectively. ${ }^{32}$ Following the European Food Safety Authority, ${ }^{50}$ the $\mathrm{RfD}$ of $\mathrm{Pb}$ is set to $1.5 \mu \mathrm{g}$ per $\mathrm{kg}$ per day. The target hazard quotients (THQS) are calculated using the average, maximum concentrations of eight metal(loid)s (Table 5). Regardless of the exposure levels utilized in the computational formula, all THQs of target elements were below 1.0 through the consumption of either fish alone, with the exception of THQ-Hg at high exposure levels. Hg shows maximum values for individual target hazard quotient (0.10), followed by As (0.069) and $\mathrm{Zn}(0.0089)$; whereas, THQs of $\mathrm{Pb}, \mathrm{Cu}, \mathrm{Cr}$, $\mathrm{Cd}$ and Ni were small (below 0.01). The total hazard index (HI) is estimated by summing each THQ value of the target metal(loid)s. The $\mathrm{HI}$ at average exposure level was 0.20 , indicating a lower health risk associated with the exposure of eight metal(loid)s. However, the $\mathrm{HI}$ at high exposure level is greater than 1.0 (1.94), suggesting a high risk from exposure to the maximum concentration of the target metal(loid)s in fish. In a sense, the accumulation of eight metal(loid)s would increase human health risks.

There are significant differences in the contribution rates of the eight metal(loid)s for $\mathrm{HI}$ at average exposure levels. Among the heavy metal elements, the contribution rate of $\mathrm{Cu}$ is the highest $(27.78 \%)$, followed by $\mathrm{Zn}(15.51 \%)$, As $(13.43 \%)$, Cd (13.01\%) and $\mathrm{Hg}(9.62 \%)$, while that of $\mathrm{Pb}, \mathrm{Cr}$ and $\mathrm{Ni}$ are quite low (all below 5.00\%). While $\mathrm{Cu}$ and $\mathrm{Zn}$ are essential elements for the human body, their excessive accumulation would be detrimental for human health. The EDIs at the average exposure levels of $\mathrm{Cu}$ and $\mathrm{Zn}$ are much lower than the RfD values, and the THQs are below 1.0, implying that $\mathrm{Cu}$ and $\mathrm{Zn}$ are not high-risk elements. Although THQs of As, $\mathrm{Cd}$ and $\mathrm{Hg}$ are below 1.0, these toxic elements could still cause serious health issues to the general public.
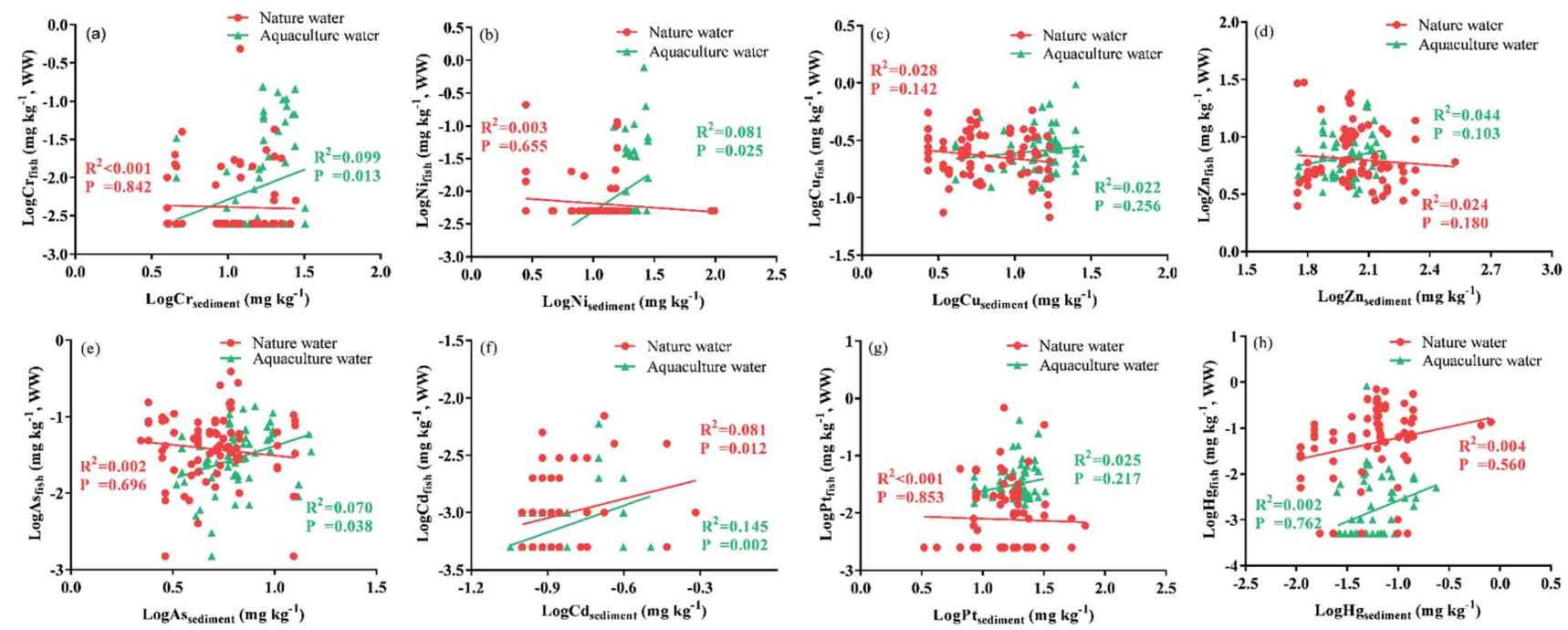

Fig. 3 The relationship between metal(loid) concentrations in fish and in their living environment. 


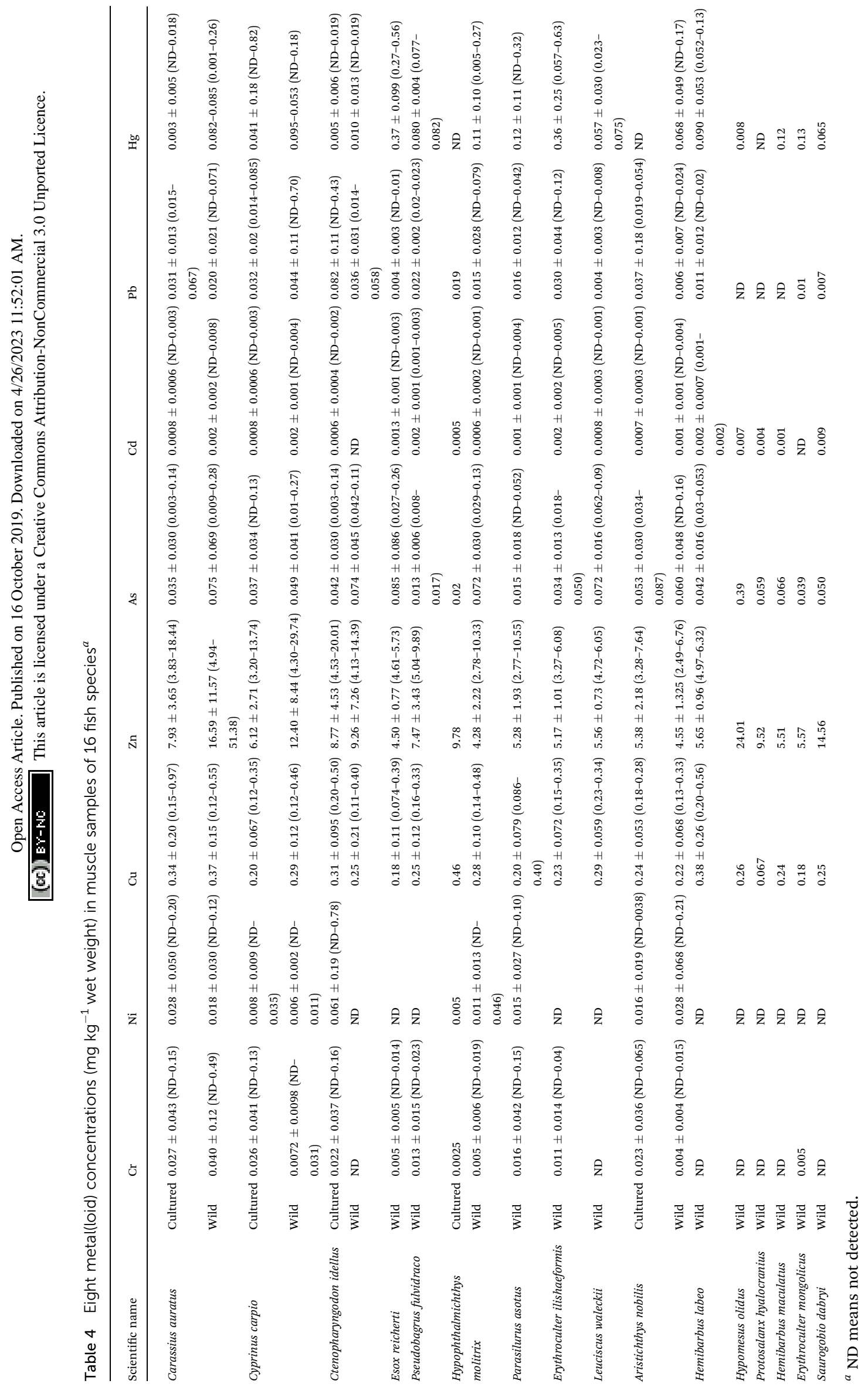


Table 5 Carcinogenic and non-carcinogenic risk analysis of elements in fish consumption in Northeast China

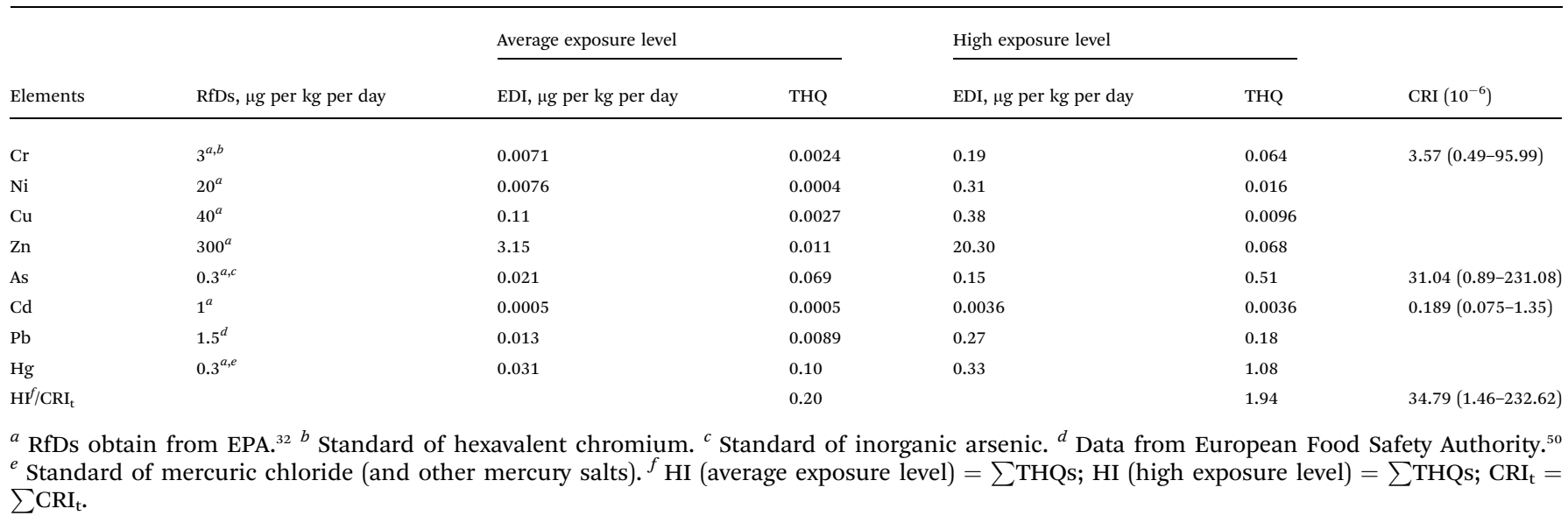

For the single element, the average carcinogenic risk indexes of $\mathrm{Cr}$, As, and Cd are all lower than $10^{-4}$ (Table 5), indicating that the carcinogenic risk of the residual metal(loid)s in the studied fish are acceptable. The total carcinogenic risk index ranges from a minimum of $1.46 \times 10^{-6}$ to a maximum of $232.62 \times$ $10^{-6}$ (an average value of $34.79 \times 10^{-6}$ ) in fish consumption in Northeast China. The results show the potential carcinogenic risk of fish consumption in Northeast China. The levels of carcinogenic elements $(\mathrm{Cr}$, As, and $\mathrm{Cd})$ in fish in this area should be monitored.

\section{Conclusions}

This study investigated the concentrations of eight metal(loid)s in fish samples from Northeast China and evaluated the health risks from fish consumption. Relative to previous studies conducted in other regions, $\mathrm{Cu}, \mathrm{Cr}, \mathrm{As}, \mathrm{Cd}$ and $\mathrm{Pb}(\mathrm{Ni}, \mathrm{Zn}$ and $\mathrm{Hg}$ ) concentrations are higher (lower) in Northeast China. Apart from individual samples, most of the fish samples have metal(loid) levels below the guideline levels and legal limits. Some sort of relationships exist between the metal(loid)s in fish and their living environment. For instance, $\mathrm{Cr}, \mathrm{Ni}$, As and $\mathrm{Cd}$ levels in cultured fish appeared to correlate with those in pond sediment. Higher detection frequencies and concentrations of As and $\mathrm{Hg}$ in wild fish indicated a certain As-pollution and $\mathrm{Hg}$ pollution in natural waters. The mean concentrations of eight metal(loid)s for each fish species are different, which might be due to different feeding habits and foraging habitats. In particular, $\mathrm{Pb}$ is the key risk factor in cultured fish, while As and $\mathrm{Hg}$ are the main risk factors in wild fish. Our results also indicate that consuming fish from Northeast China poses carcinogenic risk, and wild fish consumption would probably lead to mercury poisoning.

\section{Conflicts of interest}

There are no conflicts to declare.

\section{Acknowledgements}

This research was financially supported by Open Project of State Key Laboratory of Urban Water Resource and Environment, Harbin Institute of Technology (No. ES201604), Natural Science Foundation of Heilongjiang Province (No. QC2017033) and the Special Fund for Agro-scientific Research in the Public Interest (No. 201503108).

\section{References}

1 M. Hutton and C. Symon, Sci. Total Environ., 1986, 57, 129150.

2 H. Bing, Y. Wu, J. Zhou, R. Li and J. Wang, Chemosphere, 2016, 148, 211-219.

3 J. R. Martín, C. De Arana, J. Ramos-Miras, C. Gil and R. Boluda, Environ. Pollut., 2015, 196, 156-163.

4 S. Cheng, Environ. Sci. Pollut. Res., 2003, 10, 192-198.

5 Y. Guo and S. Yang, Sci. Total Environ., 2016, 543, 105-115.

6 J. Ren, Z. Shang, L. Tao and X. Wang, Pol. J. Environ. Stud., 2015, 24, 1041-1048.

7 W. Wildi, J. Dominik, J. L. Loizeau, R. L. Thomas, P. Y. Favarger, L. Haller, A. Perroud and C. Peytremann, Lakes Reservoirs: Res. Manage., 2004, 9, 75-87.

8 H. Nussey, Water SA, 2000, 26, 269-284.

9 A. G. Heath, Water Pollution and Fish Physiology, CRC Press, Boca Raton, Florida, U.S.A, 1987.

10 Y. Liu, G. Liu, Z. Yuan, H. Liu and P. K. Lam, Sci. Total Environ., 2018, 613, 462-471.

11 Y. G. Gu, Q. Lin, H.-H. Huang, L. g. Wang, J. J. Ning and F. Y. Du, Mar. Pollut. Bull., 2017, 114, 1125-1129.

12 J. L. Liu, X.-R. Xu, Z. H. Ding, J. X. Peng, M. H. Jin, Y. S. Wang, Y. G. Hong and W. Z. Yue, Ecotoxicology, 2015, 24, 15831592.

13 I. Jæger, H. Hop and G. W. Gabrielsen, Sci. Total Environ., 2009, 407, 4744-4751.

14 N. L. Gale, C. D. Adams, B. G. Wixson, K. A. Loftin and H. Yue-Wern, Environ. Sci. Technol., 2002, 36, 4262-4268. 
15 L. Atwell, K. A. Hobson and H. E. Welch, Can. J. Fish. Aquat. Sci., 1998, 55, 1114-1121.

16 V. Sirot, T. Guérin, J. L. Volatier and J.-C. Leblanc, Sci. Total Environ., 2009, 407, 1875-1885.

17 S. Rajeshkumar, Y. Liu, X. Zhang, B. Ravikumar, G. Bai and X. Li, Chemosphere, 2018, 191, 626-638.

18 Y.-J. Yi and S.-H. Zhang, Environ. Sci. Pollut. Res., 2012, 19, 3989-3996.

19 A. Mountouris, E. Voutsas and D. Tassios, Mar. Pollut. Bull., 2002, 44, 1136-1141.

20 C. Y. Chen and C. L. Folt, Environ. Sci. Technol., 2000, 34, 3878-3884.

21 A. Goutte, Y. Cherel, C. Churlaud, J.-P. Ponthus, G. Massé and P. Bustamante, Sci. Total Environ., 2015, 538, 743-749.

22 H. Leung, A. Leung, H. Wang, K. Ma, Y. Liang, K. Ho, K. Cheung, F. Tohidi and K. Yung, Mar. Pollut. Bull., 2014, 78, 235-245.

23 G. B. Jiang, J. B. Shi and X. B. Feng, Environ. Sci. Technol., 2006, 40, 3672-3678.

24 L. Bingli, S. Huang, Q. Min, L. Tianyun and W. Zijian, J. Environ. Sci., 2008, 20, 769-777.

25 N. Li, Y. Tian, J. Zhang, W. Zuo, W. Zhan and J. Zhang, Environ. Sci. Pollut. Res., 2017, 24, 3214-3225.

26 D. Qin, H. Jiang, X. Huang, L. Gao, Z. Chen, Z. Mou and L. I. Gang, Acta Sci. Circumstantiae, 2016, 36, 1910-1916.

27 K. Pan and W.-X. Wang, Sci. Total Environ., 2012, 421, 3-16.

28 D. Qin, H. Jiang, S. Bai, S. Tang and Z. Mou, Food Control, 2015, 50, 1-8.

29 H. Jiang, D. Qin, Z. Chen, S. Tang, S. Bai and Z. Mou, Bull. Environ. Contam. Toxicol., 2016, 97, 536-542.

30 FAO, in Heavy Metals Regulations Legal Notice No 66/2003, FAO, Rome, 2003.

31 F. Zhai, H. Wang, S. Du, Y. He, Z. Wang, K. Ge and B. M. Popkin, Nutr. Rev., 2009, 67, S56-S61.

32 EPA, in Regional Screening Level (RSL) Resident Fish Table, United States Environmental Protection Agency, Washington DC, 2018.
33 EPA, Guidance for Assessing Chemical Contaminant Data for Use in Fish Advisories, Risk Assessment and Fish Consumption Limits, Washington DC, 2000.

34 NHFPC, National standards for food safety-contaminants limit in food, 2017, GB 2762-2017.

35 SAC, Non-environmental Pollution Food-limit of Poisonous and Harmful Substances in Aquatic Products, NY, 2006, pp. 50732006.

36 EC, in Official Journal of the European Union, No. 1881/2006, 2015.

$37 \mathrm{DOH}$, in Foodstuffs, cosmetics and disinfectants act, 1972 (Act no. 54 of 1972), Government Gazette, 2004.

38 R. Nakagawa, Y. Yumita and M. Hiromoto, Chemosphere, 1997, 35, 2909-2913.

39 M. S. Rahman, A. H. Molla, N. Saha and A. Rahman, Food Chem., 2012, 134, 1847-1854.

40 C. Ip, X. Li, G. Zhang, C. Wong and W. Zhang, Environ. Pollut., 2005, 138, 494-504.

41 R. Yang, T. Yao, B. Xu, G. Jiang and X. Xin, Environ. Int., 2007, 33, 151-156.

42 M. Canli and G. Atli, Environ. Pollut., 2003, 121, 129-136.

43 K. A. Asante, T. Agusa, H. Mochizuki, K. Ramu, S. Inoue, T. Kubodera, S. Takahashi, A. Subramanian and S. Tanabe, Environ. Pollut., 2008, 156, 862-873.

44 Y. Yujun, W. Zhaoyin, K. Zhang, Y. Guoan and D. Xuehua, Int. J. Sediment Res., 2008, 23, 338-347.

45 R. D. Handy and F. B. Eddy, J. Fish Biol., 1989, 34, 865-874. 46 H. Zhou and M. H. Wong, Water Res., 2000, 34, 4234-4242.

47 H. Zhu, B. Yan, H. Cao and L. Wang, Environ. Monit. Assess., 2012, 184, 77-88.

48 J. Reinfelder, N. Fisher, S. Luoma, J. Nichols and W. X. Wang, Sci. Total Environ., 1998, 219, 117-135.

49 L. M. Campbell, R. J. Norstrom, K. A. Hobson, D. C. Muir, S. Backus and A. T. Fisk, Sci. Total Environ., 2005, 351, 247-263.

50 EFSA, EFSA J., 2010, 8, 1570. 